\title{
KEBUTUHAN RUANG TRANSISI DI KAWASAN CBD KOTA BANDUNG BERDASARKAN PREFERENSI DAN PERSEPSI PEJALAN KAKI
}

\author{
The Need of Transition Space in Bandung CBD Based on Preference \\ and Peception of Pedestrians
}

\author{
Witanti Nur Utami ${ }^{1}$, Petrus N.Indradjati ${ }^{2}$, Heru W.Poerbo ${ }^{3}$
}

Diterima: 11 Agustus 2017

Disetujui: 26 April 2018

\begin{abstract}
Abstrak: Kawasan pusat kota memiliki daya tarik bagi seseorang untuk berkunjung maupun bekerja di kawasan tersebut. Berkaitan dengan aktivitas tersebut khususnya kegiatan berjalan kaki, terdapat kebutuhan yang seharusnya menjadi pertimbangan di dalam memenuhi fasilitas bagi pejalan kaki yaitu keberadaan ruang transisi. Sejauh ini, kebutuhan ruang transisi di perkotaan Indonesia belum jelas diatur dan dipertimbangkan terkait perancangan ruang transisi yang dapat digunakan oleh pejalan kaki di pusat kota serta belum adanya studi terkait aspek-aspek yang perlu diperhatikan di dalam perancangan kebutuhan ruang transisi di perkotaan dari sisi pejalan kaki. Tujuan penelitian ini untuk merancang kebutuhan ruang transisi di CBD. Penelitian ini menggunakan pendekatan preferensi pejalan kaki pengunjung dan pekerja. Selain preferensi, yang perlu dilihat dalam merancang ruang transisi yaitu analisa terhadap kondisi, potensi serta faktor-faktor yang mempengaruhi keberadaan ruang transisi, sehingga dari masing-masing hasil tersebut didapatkan suatu prinsip perancangan ruang transisi di CBD Kota Bandung. Hasil penelitian menunjukkan bahwa berdasarkan preferensi dan persepsi, ruang transisi pada kawasan pusat Kota Bandung yang paling diminati oleh pejalan kaki pengunjung dan pekerja merupakan ruang transisi dengan bentuk external public space yaitu jenis pedestrian mall. Selain itu, dihasilkan rumusan prinsip perancangan berdasarkan komponen bentuk, akses, dan karakter ruangnya.
\end{abstract}

Kata kunci: CBD, ruang transisi, pejalan kaki, preferensi, prinsip perancangan

\begin{abstract}
City center is an urban place which always attract people either for visit or work purpose. Those activities generates pedestrian traffic that needs to be managed by providing transition space. So far, the need of transition space in urban Indonesia has not been clearly regulated and considered related to the design of transition space that can be use by pedestrians in the city center. Furthermore, there are no studies related to the aspects that need to be considered in the design needs of urban transition space from pedestrians point of view. The study aims to design transition space requirements in the CBD through a visitor and worker pedestrian preferences approach. Moreover, physical aspect / design element that need to be considered are conditions, potentials and factors that affect the existence of transition place. Field study and analysis found that visitor and workers found in Bandung central area mostly prefer pedestrian mall type as a transition space. Furthermore, the design principles for transition space consists of component of form, access and the character of space.
\end{abstract}

Keywords: $C B D$, design principle, pedestrian, preference, transition space

\footnotetext{
${ }^{1}$ Prodi Magister Rancang Kota Institut Teknologi Bandung

${ }^{2}$ Kelompok Keahlian Perencanaan dan Perancangan Kota, Institut Teknologi Bandung

${ }^{3}$ Kelompok Keahlian Perancangan Arsitektur, Institut Teknologi Bandung
} 


\section{PENDAHULUAN}

Kawasan pusat kota memiliki karakteristik utama di mana terdapat kegiatan yang kompleks dan beragam serta kegiatan atau fungsi kawasan yang memiliki nilai sosialekonomi yang sangat tinggi sekaligus merupakan tempat berkumpul orang dengan jumlah yang besar di dalam melakukan suatu kegiatan (Pawitro, 2015). Berdasarkan karakteristiknya tersebut, keberadaan ruang transisi menjadi pertimbangan yang relevan di dalam mengisi fungsi ruang di pusat kota khususnya ditujukan untuk pedestrian.

Ruang transisi dalam penelitian ini merupakan ruang yang dapat berada di antara ruang publik dan ruang privat sehingga keberadaannya dapat menjadi ruang semi publik yang ditujukan untuk pejalan kaki. Adapun ruang tersebut berperan menjadi ruang perantara di perkotaan yang memiliki keterhubungan (koneksi) di antara fungsi ruang privat (komersial, perkantoran) dan fungsi ruang publik (urban public space) yang pada akhirnya difungsikan sebagai ruang 'pertemuan' bagi pejalan kaki di pusat kota untuk memulai aktivitas baru dari aktivitas yang terjadi sebelumnya. Ruang tersebut dapat digunakan untuk beristirahat dari berjalan kaki ataupun ruang yang digunakan oleh pekerja saat jam istirahat/selepas aktivitas bekerja.

Terdapat beberapa persoalan terkait ruang transisi di pusat kota (CBD) yaitu ruang transisi tidak dirancang dengan mempertimbangkan preferensi pejalan kaki akan kebutuhan terhadap ruang transisi, belum diketahuinya bentuk-bentuk ruang transisi yang dibutuhkan oleh pejalan kaki dan ketersediaan akan potensi ruang di CBD serta belum diketahuinya kebutuhan preferensi pejalan kaki terhadap ruang transisi yang seperti apa yang seharusnya ada di CBD.

Berdasarkan uraian di atas, maka tujuan dari penelitian ini yaitu merancang ruang transisi di CBD berdasarkan preferensi pejalan kaki. Dalam jurnal ini, tujuan penelitian diturunkan ke dalam empat sasaran yaitu terumuskannya aspek dan kriteria perancangan yang perlu dipertimbangkan dalam merancang ruang transisi berdasarkan literatur, teridentifikasinya kebutuhan ruang transisi bagi pejalan kaki berdasarkan preferensi mereka terhadap ruang transisi, teridentifikasinya kondisi dan potensi ruang transisi yang terbentuk pada kawasan pusat kota (CBD) serta terumuskannya faktor-faktor perancangan yang mempengaruhi ruang transisi di CBD.

\section{METODE PENELITIAN}

Penelitian ini dilakukan menggunakan metode kuantitatif melalui pendekatan preferensi pejalan kaki pengunjung dan pekerja. Preferensi merupakan suatu kecenderungan untuk memilih sesuatu yang lebih disukai daripada yang lainnya, preferensi merupakan bagian dari hasil komponen pembuatan keputusan dari seorang individu (Porteus, 1997). Metode tersebut memberikan sajian data yang akurat mengenai trend, perilaku atau opini dari suatu populasi dengan mempelajari sampel yang didapat dari populasi tersebut (Creswell, 2003).

Metode pengumpulan data dalam penelitian ini terbagi dua, yaitu metode pengumpulan data primer dan pengumpulan data sekunder. Pengumpulan data primer dilakukan melalui observasi dan penyebaran kuesioner terhadap 200 responden pejalan kaki melalui cara non probabilitas dengan teknik accidental sampling, teknik penentuan sampel berdasarkan kebetulan, yaitu siapa saja yang secara kebetulan bertemu dengan peneliti dapat digunakan sebagai sampel, bila dipandang orang yang kebetulan ditemui itu cocok sebagai sumber data (Sugiyono, 2005). Teknik tersebut dilakukan berdasarkan kondisi pengunjung di pusat kota yang tidak memiliki populasi yang khusus dalam menginformasikan kunjungan dalam periode waktu, di mana kawasan pusat kota merupakan kawasan yang banyak dikunjungi oleh masyarakat umum, dan sejauh ini tidak ada catatan resmi yang menunjukkan banyaknya kunjungan masyarakat baik itu dalam periode sehari, 
sebulan ataupun dalam waktu setahun begitu juga dengan populasi pekerja yang bekerja di pusat kota yang tidak diketahui jumlahnya. Adapun pengambilan sampel dilakukan dengan menyebarkan kuesioner pada tiga pusat kegiatan di kawasan studi yang dapat mendorong orang untuk berjalan kaki di kawasan tersebut, yakni meliputi pusat kegiatan Pasar Baru, $\mathrm{ABC}$, dan Alun-Alun.

Kuesioner dalam penelitian ini berfungsi untuk menggali informasi terkait preferensi pengunjung pusat kota dan para pekerja yang bekerja di pusat kota terkait ruang transisi di Kawasan Pusat Kota Bandung. Selain itu, didapat juga data sekunder melalui pengumpulan data yang dilakukan dengan mengumpulkan dokumen-dokumen dari sumber literatur terkait dan dokumen pemerintahan.

Lokasi penelitian yaitu Kawasan Pusat Kota Bandung di mana kawasan studi merupakan bagian dari salah satu kawasan Pusat Pelayanan Kota (PPK) yang bernamakan PPK Alun-Alun. Batas kawasan studi yaitu di bagian utara Jalan Stasiun Timur, bagian selatan Jalan Simpang, bagian timur Jalan Braga, dan bagian Barat Jalan Dulatip dengan luas kawasan studi $\pm 69,5 \mathrm{Ha}$.

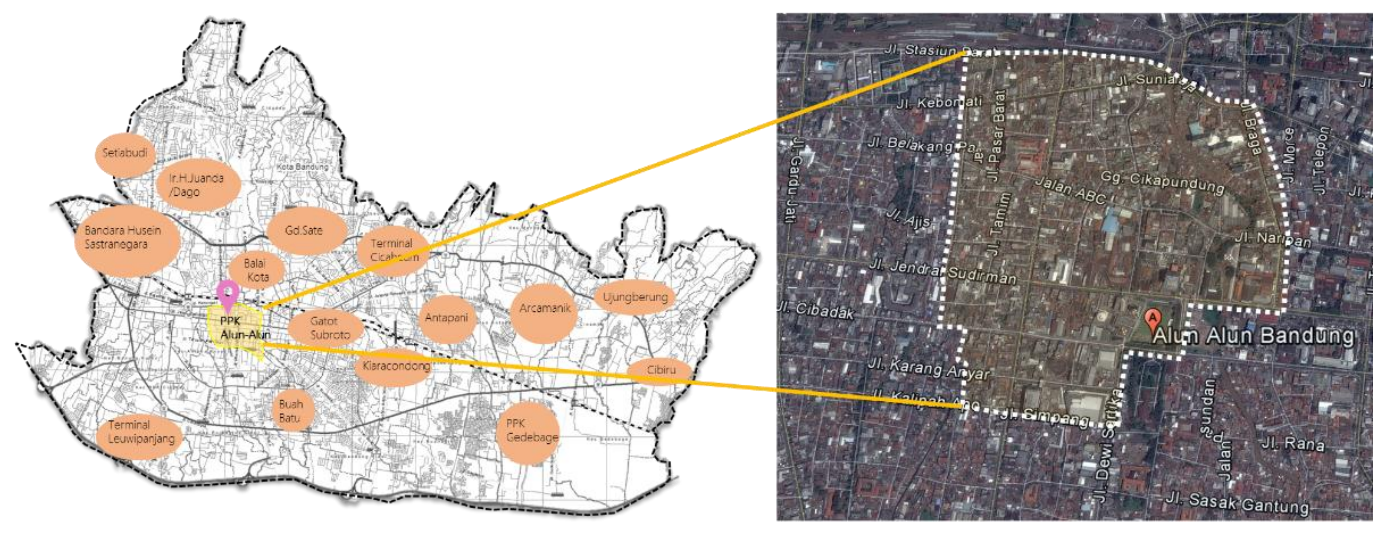

Sumber: RTRW Kota Bandung 2011-2031, Google Maps

\section{Gambar 1. Kedudukan Kawasan Studi Pada Lingkup Kota Bandung}

Secara umum, ruang transisi merupakan salah satu hierarki ruang yang merupakan ruang peralihan yang membentuk suatu hubungan antara dunia di dalam dan dunia di luar, (Lao Tzu dalam Surasetja, 2007), ruang transisi juga dapat dianggap sebagai properti dasar keberadaan manusia (Schulz \& Christiani, 1971). Adapun kaitannya dengan ruang luar perkotaan (urban outdoor space), transisi mempengaruhi lingkungan fisik dari fungsi kota itu sendiri, yang mana pada akhirnya mempengaruhi pengalaman seseorang. Pengalaman tersebut berkaitan dengan pejalan kaki di pusat kota yang sedang berada pada 'ruang luar', yang mana pengalaman-pengalaman tersebut didapatkan ketika pejalan kaki melakukan aktivitasnya di pusat kota. Pada public setting, transisi dapat bervariasi dalam skalanya yang kemudian hal tersebut berhasil menciptakan ruang luar yang elastis (Singh, 2015). Ruang transisi dapat dipandang juga sebagai tempat yang memiliki kontrol atas privasi, gerakan serta mencakup perlindungan ruang dari pandangan luar (Asadi, Tahir, Shabani, \& Arjmandi, 2015). Kondisi tersebut berkaitan dengan maknanya sebagai proses perubahan dari satu kondisi ke kondisi yang lain, di mana terletak di antara 'ruang luar' dan 'ruang dalam' pada suatu lingkungan, sekaligus bertindak sebagai ruang penyangga maupun penghubung secara fisik, selain berfungsi sebagai rute sirkulasi bagi bangunan (Nassar \& El-Samaty , 2007). 
Adapun peran ruang transisi dapat dikategorikan sebagai spatial roles, utilitarian roles, dan semantic roles (El-Fattah El-Mokadem, Sallam, \& Salah El-Samaty, 2013), yang masingmasing kategori memiliki perannya masing-masing. Adapun berkaitan dengan ruang transisi bagi pejalan kaki, maka peran ruang transisi lebih kepada ruang spasial (spatial roles) di mana ruang transisi memiliki peran untuk mewadahi aktivitas pejalan kaki sebagai ruang pertemuan pejalan kaki sekaligus untuk peristirahatan sementara dan menjadi 'penyangga' antar ruang yang berbeda, dalam hal ini ruang-ruang dengan fungsinya sebagai tujuan awal pengunjung dan pekerja (pusat perbelanjaan, pertokoan, serta tempat kerja) di pusat kota dengan ruang yang dibutuhkan oleh pejalan kaki ketika aktivitas sebelumnya telah dilakukan, yaitu ruang transisi.

Selain itu juga, ruang transisi bagi pejalan kaki ini berperan sebagai ruang penggunaan (utilitarian roles), di mana perannya untuk mengarah pada tujuan dan sebagai pergerakan antar tempat dalam hal ini tempat tujuan di awal kedatangan pengunjung dan pekerja di pusat kota serta pergerakan ke tempat tujuan berikutnya yang akan dilakukan oleh pejalan kaki, yaitu pada ruang transisi.

Ruang transisi bagi pejalan kaki, maka ruang tersebut sepenuhnya merupakan ruang yang dapat berupa publik, privat ataupun semi publik yang difungsikan sebagai ruang pertemuan pejalan kaki di pusat kota untuk memulai aktivitas baru dari aktivitas yang terjadi sebelumnya. Ruang tersebut dapat digunakan untuk beristirahat dari berjalan kaki ataupun ruang yang digunakan oleh pekerja saat jam istirahat/selepas jam kerja. Ruang transisi bagi pejalan kaki di CBD tentunya berkaitan dengan komponen bentuk/jenis ruang yang dapat dijadikan sebagai ruang transisi, komponen akses dan karakter ruang yang terbentuk dalam mendukung sebuah ruang transisi (Gambar 3).

Sumber: (Kent, 1990), (Singh, 2015)
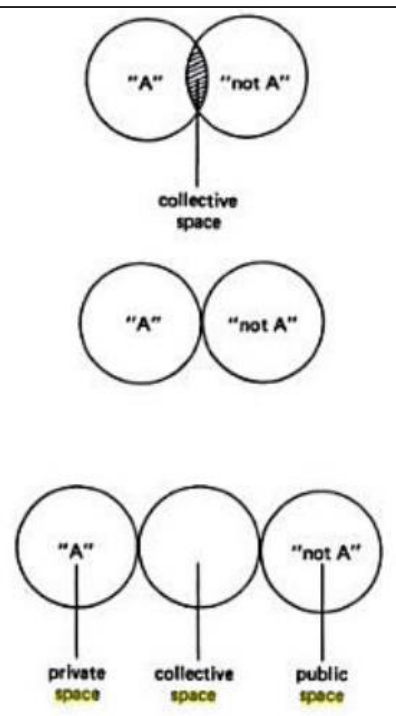

Gambar 2. Diagram Hubungan Ruang Transisi dengan Ruang yang Lain

Komponen ruang transisi terkait bentuk mengarah kepada tipologi bentuk dan jenis ruang yang dapat digunakan oleh pejalan kaki, di mana akses yang perlu diperhatikan yaitu terkait kondisi lingkungan fasilitas pedestrian yang melibatkan permeability, continuity serta walkability. Selain itu juga, karakter ruang transisi yang melibatkan kualitas fisik, aktivitas, serta lingkungan yang responsif dalam menciptakan ruang transisi. 


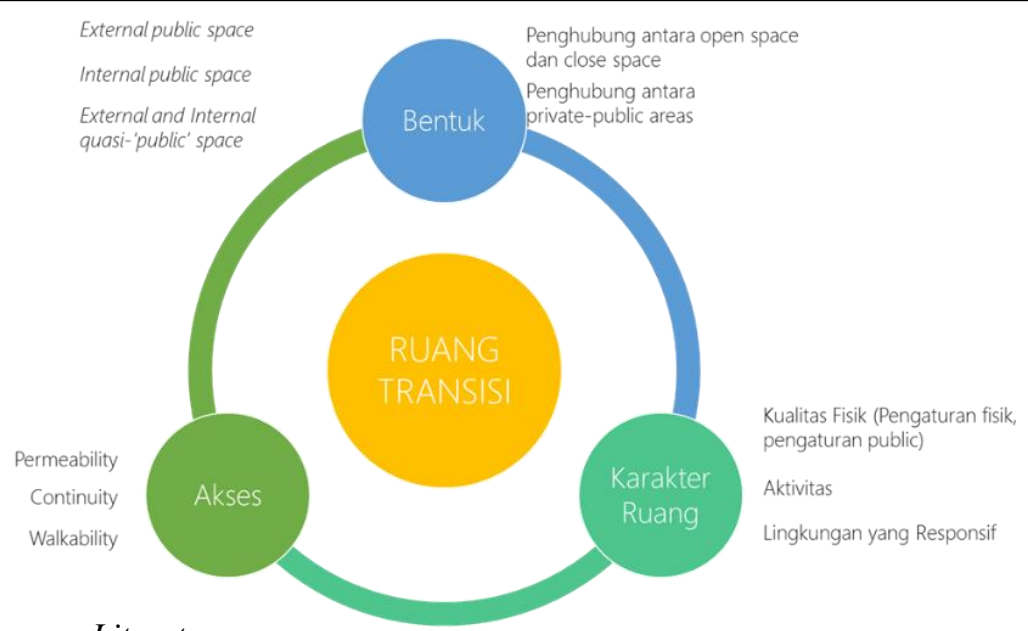

Sumber: Sintesa Penelurusan Literatur

Gambar 3. Komponen Ruang Transisi Pejalan Kaki

Tabel 1. Komponen dan Indikator Penelitian

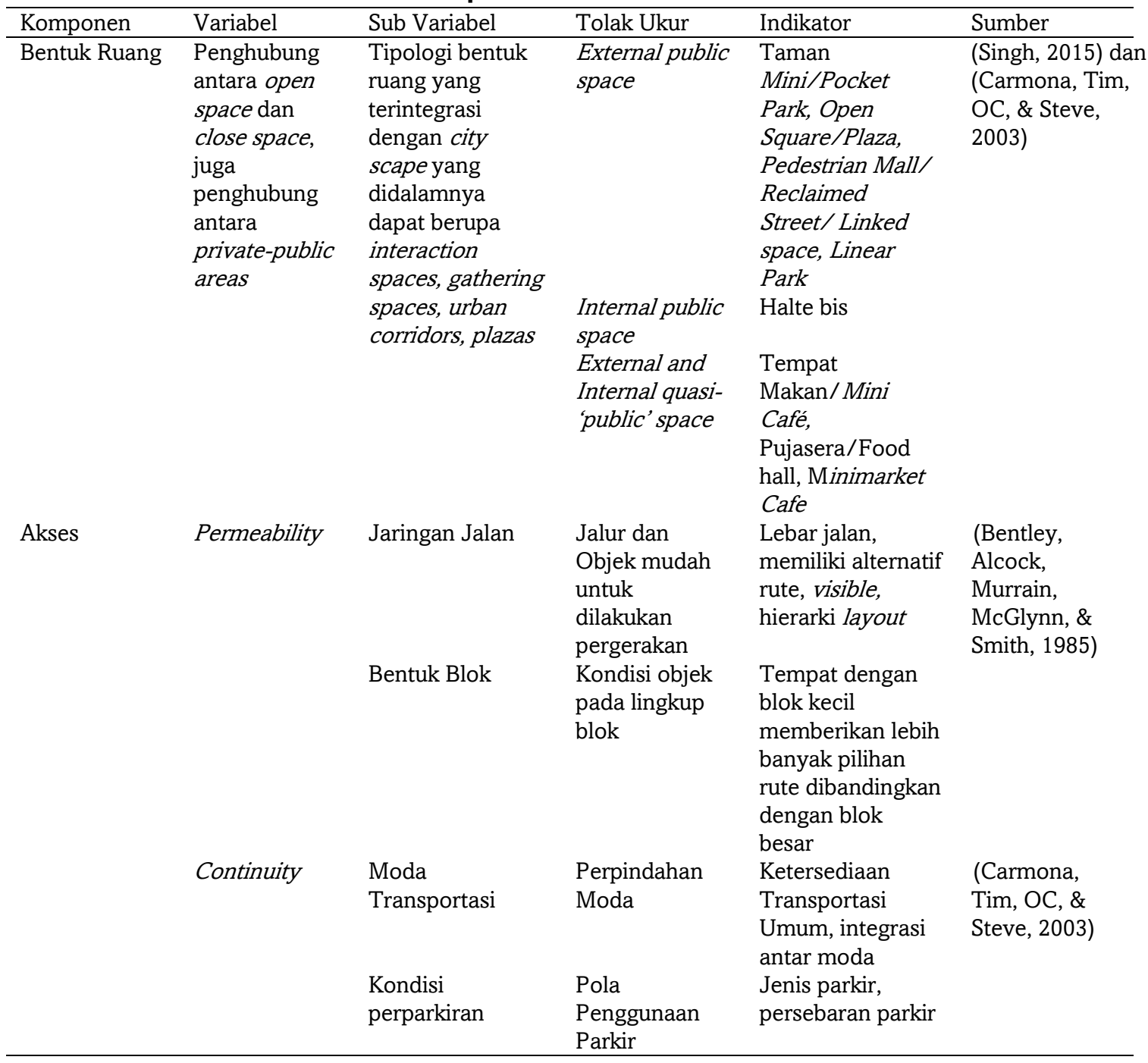




\begin{tabular}{|c|c|c|c|c|c|}
\hline Komponen & Variabel & Sub Variabel & Tolak Ukur & Indikator & Sumber \\
\hline \multirow{8}{*}{$\begin{array}{l}\text { Karakter } \\
\text { Ruang }\end{array}$} & Walkability & $\begin{array}{l}\text { Lingkungan } \\
\text { pedestrian }\end{array}$ & $\begin{array}{l}\text { Kenyamanan } \\
\text { ketika berjalan } \\
\text { pada suatu } \\
\text { lingkungan }\end{array}$ & $\begin{array}{l}\text { Connected, } \\
\text { comfortable, } \\
\text { convivial, } \\
\text { conspicuosness, } \\
\text { convenience }\end{array}$ & $\begin{array}{l}\text { (LLwelyn- } \\
\text { Davies, 2000) }\end{array}$ \\
\hline & & Walking Distance & $\begin{array}{l}\text { Kemampuan } \\
\text { jarak } \\
\text { seseorang } \\
\text { berjalan kaki di } \\
\text { pusat kota }\end{array}$ & $\begin{array}{l}\text { Variasi jarak } \\
\text { berjalan kaki }\end{array}$ & $\begin{array}{l}\text { (Untermann, } \\
\text { 1984) }\end{array}$ \\
\hline & Kualitas Fisik & Physical Setting & Kualitas Visual & $\begin{array}{l}\text { Fit with setting, } \\
\text { Ekspression of } \\
\text { identity, Access \& } \\
\text { Orientation, } \\
\text { Activity Support, } \\
\text { View, Natural } \\
\text { Elements, visual } \\
\text { comfort, Care and } \\
\text { Maintanance }\end{array}$ & $\begin{array}{l}\text { (Shirvani, } \\
\text { 1985) }\end{array}$ \\
\hline & \multirow{5}{*}{ Aktivitas } & Public Setting & $\begin{array}{l}\text { Karakteristik } \\
\text { Fisik }\end{array}$ & $\begin{array}{l}\text { Location, } \\
\text { Avaibility of } \\
\text { seating, A vaibility } \\
\text { of food, } \\
\text { Greenary, } \\
\text { relation to } \\
\text { movement, } \\
\text { Ability to see } \\
\text { activity, Children } \\
\text { play areas, } \\
\text { Presence of shop, } \\
\text { Copresence of } \\
\text { other people, sun, } \\
\text { trees, and water, } \\
\text { shelter from wind } \\
\text { and rain }\end{array}$ & $\begin{array}{l}\text { (Rapoport, } \\
\text { 1990) }\end{array}$ \\
\hline & & & Ideal Space & $\begin{array}{l}\text { Spacious, } \\
\text { Relaxing, } \\
\text { Peaceful, Colorful }\end{array}$ & \\
\hline & & Vitality & Liveliness & $\begin{array}{l}\text { Pola Guna Lahan, } \\
\text { Jam Aktif } \\
\text { Kawasan, Street } \\
\text { Activity, Activity } \\
\text { Support }\end{array}$ & $\begin{array}{l}\text { (Carmona, } \\
\text { Tim, OC, \& } \\
\text { Steve, 2003), } \\
\text { (Montgomery, } \\
\text { 1998), dan } \\
\text { (Ujang, 2010) }\end{array}$ \\
\hline & & \multirow[t]{2}{*}{ Diversity } & $\begin{array}{l}\text { Jenis aktivitas } \\
\text { yang dapat } \\
\text { dilakukan, } \\
\text { Sejauh mana } \\
\text { variasi dalam } \\
\text { penggunaan } \\
\text { lahan di } \\
\text { kawasan }\end{array}$ & $\begin{array}{l}\text { Daftar jenis } \\
\text { aktivitas Sitting, } \\
\text { Eating,Socializing, } \\
\text { Resting, Talking }\end{array}$ & $\begin{array}{l}\text { (Rapoport, } \\
1990 \text { ) }\end{array}$ \\
\hline & & & $\begin{array}{l}\text { Sejauh mana } \\
\text { variasi dalam } \\
\text { penggunaan } \\
\text { lahan di } \\
\text { kawasan }\end{array}$ & $\begin{array}{l}\text { Patterns in } \\
\text { opening hours, } \\
\text { including the } \\
\text { existence of } \\
\text { evening and } \\
\text { night-time } \\
\text { Activity, Presence } \\
\text { of an active street }\end{array}$ & $\begin{array}{l}\text { (Montgomery, } \\
1998 \text { ) }\end{array}$ \\
\hline
\end{tabular}




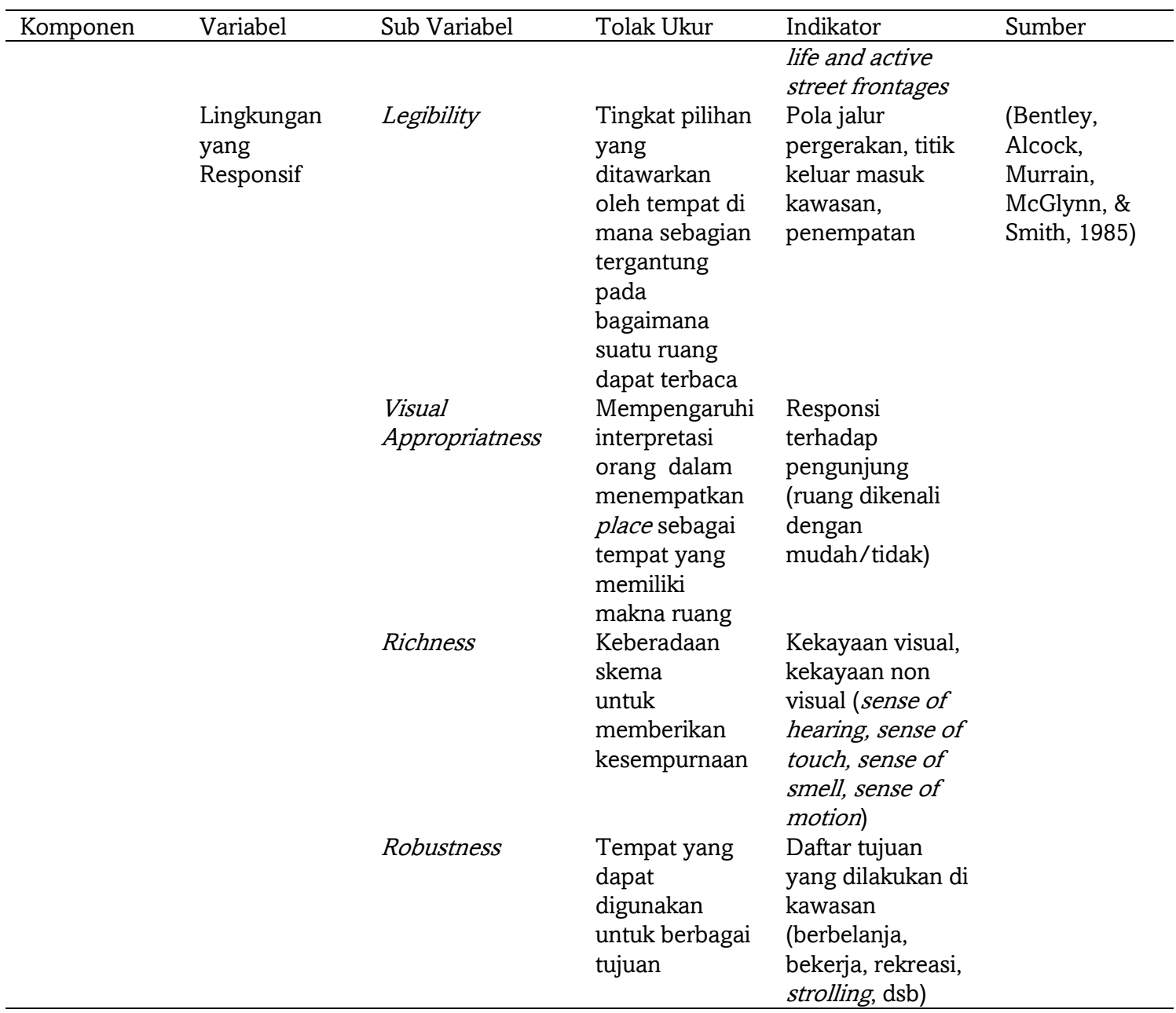

Berkaitan dengan komponen yang dijelaskan di atas, terutama berkaitan dengan kemampuan jarak seseorang berjalan kaki di pusat kota maka berkaitan dengan variasi jarak yang dilakukan oleh seseorang, yang mana jarak merupakan salah satu faktor yang mempengaruhi panjang pergerakan orang untuk berjalan kaki (Untermann, 1984). Jarak berjalan kaki yang biasa dilakukan oleh pejalan kaki di kawasan pusat kota dapat dimulai dengan jarak dekat (100-200 m), (200-400 m), dan (>400 m) (Utami \& Kesuma, 2016). Adapun terdapat enam faktor yang mempengaruhi kebutuhan area transisi di pusat Kota Bandung yang dilihat berdasarkan jarak berjalan kaki seseorang yaitu meliputi kenyamanan fisik, ruang publik, unsur lanskap, kualitas visual, fasilitas pendukung, dan kuliner, namun faktor-faktor yang berpengaruh dan signifikan terkait kebutuhan area transisi berdasarkan jarak berjalan kaki di Kawasan Pusat Kota Bandung yaitu hanya tiga faktor, ruang publik, kualitas visual, dan fasilitas pendukung. Adapun komponen dari faktor Ruang Publik meliputi Mini Café, Plaza Mini, dan Taman Mini. Komponen kualitas visual meliputi pattern/pola lantai dan desain yang menarik, serta komponen untuk fasilitas pendukung meliputi jalur pedestrian yang baik, sarana air minum, tempat sampah, dan signage/penanda (Utami \& Kesuma, 2016).

\section{HASIL DAN PEMBAHASAN}

Terdapat integrasi antara pusat-pusat kegiatan di CBD Kota Bandung dengan ruang transisi yang tampak melalui karakteristik pola pergerakan pejalan kaki yang dilakukan pengunjung dan pekerja. Oleh karena itu, preferensi pejalan kaki terhadap keberadaan ruang 
transisi berdasarkan komponen bentuk ruang, akses, serta karakter ruang, sangat penting dalam merumuskan prinsip perancangannya baik dalam konteks kawasan CBD serta prinsip perancangan ruang transisi berdasarkan bentuk/jenisnya di mana yang paling diminati oleh pejalan kaki.

\section{Karakteristik Kawasan Studi}

Kawasan studi merupakan kawasan pusat Kota Bandung (PPK Alun-Alun) yang merupakan kawasan strategis dari sudut kepentingan ekonomi serta merupakan bagian dari kawasan yang mencakup Kawasan Pusat Kota Bersejarah dan Kawasan Pecinan/Perdagangan (RTRW Kota Bandung 2011-2031). Kawasan studi ini memiliki pusatpusat kegiatan yang dapat mendorong orang untuk berjalan kaki, yaitu pusat kegiatan Pasar Baru, ABC, dan Alun-Alun.

Tabel 2. Karakteristik Pusat Kegiatan di Kawasan Studi

\begin{tabular}{|c|c|}
\hline Pusat Kegiatan & Karakteristik \\
\hline Pasar Baru & $\begin{array}{l}\text { Kawasan pengembangan pariwisata yang } \\
\text { termasuk ke dalam daya tarik wisata primer yang } \\
\text { mendukung pengembangan kawasan sebagai } \\
\text { kawasan pariwisata belanja Otto Iskandardinata } \\
\text { Aktivitas yang dominan yaitu perdagangan } \\
\text { kain/tekstil, aksesoris, dan jasa dengan } \\
\text { karakteristik bangunan rata-rata paling banyak } \\
\text { yaiu } 1-2 \text { lantai, namun ada juga yang memiliki } \\
\text { lantai >5 lantai yang berada di beberapa di antara } \\
\text { bangunan dominan } 1-2 \text { lantai } \\
\text { Jam aktivitas yang berlangsung rata-rata yang } \\
\text { berlangsung yaitu pukul } 09.00 \text { s.d } 17.00 \text {. }\end{array}$ \\
\hline & $\begin{array}{l}\text { Perdagangan deret yang menjual peralatan rumah } \\
\text { tangga, elektronik, dan optik } \\
>\text { Perdagangan deret ini didominasi dengan } \\
\text { bangunan 1-2 lantai juga dan juga ada beberapa } \\
\text { bangunan } 2-3 \text { lantai hingga }>5 \text { lantai } \\
>\text { Rata-rata jam aktivitas pada kawasan ini yaitu } \\
\text { mulai buka toko pada pukul } 08.00 \text { s.d } 18.00 \text {. }\end{array}$ \\
\hline Alun-Alun & $\begin{array}{l}\text { Kawasan yang masuk ke dalam kawasan strategis } \\
\text { pariwisata daerah berupa kawasan pariwisata } \\
\text { warisan budaya Alun-Alun-Braga } \\
\text { Kawasan yang melibatkan fungsi ruang terbuka } \\
\text { publik seperti plaza masjid serta kawasan } \\
\text { perdagangan dan jasa yang berada di sekitarnya } \\
>\text { Rata-rata jumlah lantai pada pusat kegiatan ini } \\
\text { yaitu paling banyak 2-3 lantai, namun ada juga } \\
\text { beberapa yang variasi yaitu 1-2 lantai , 3-4, dan >5 } \\
\text { lantai } \\
\text { Rata-rata jam aktivitas pada pusat kegiatan ini } \\
\text { yaitu pukul } 09.00 \text { s.d } 21.00\end{array}$ \\
\hline
\end{tabular}




\section{Karakteristik Pola Berjalan Kaki Pedestrian}

Berdasarkan tiga pusat kegiatan yang ada, maka banyak pejalan kaki khususnya pengunjung (44\%) berkunjung ke pusat kota dalam rangka untuk berbelanja dan (38\%) untuk jalan-jalan, dengan frekuensi paling banyak (56\%) yaitu 2 minggu satu kali dengan dominasi penggunaan kendaraan pribadi.

Penggunaan kendaraan pribadi dengan tujuan pusat kota yaitu berupa pengguna motor sebanyak $60 \%$ pengunjung dan pekerja serta mobil sebanyak $18 \%$ pengunjung dan $1 \%$ pekerja dengan titik pemberhentian paling banyak (38\%) pengunjung dan pekerja (39\%) pada parkir off-street. Selain kendaraan pribadi, juga alternatif kendaraan umum menjadi pilihan bagi pengunjung dan pekerja ketika menuju pusat kota, di mana kendaraan umum yang paling diminati yaitu angkot, $10 \%$ pengunjung dan $18 \%$ pekerja memilih moda tersebut. Terdapat kondisi ketika para pekerja memiliki tempat tinggal yang berada dekat dengan tempat bekerjanya, sehingga $18 \%$ pejalan kaki pekerja menuju tempat kerjanya yang berada di pusat kota dengan cara berjalan kaki, lihat Gambar 4.

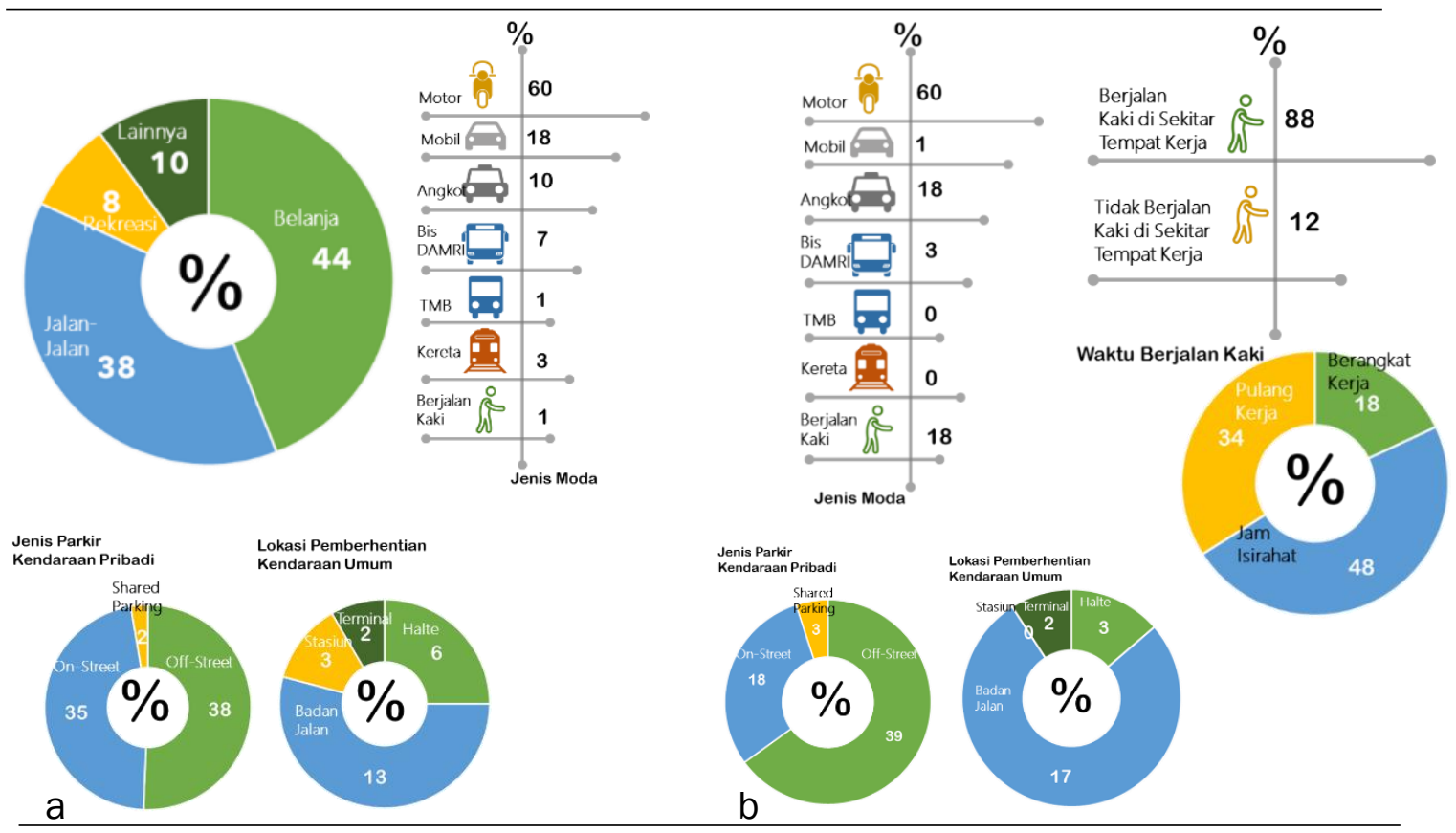

\section{Gambar 4. (a) Karakteristik Pejalan Kaki Pengunjung; (b) Karakteristik Pejalan Kaki Pekerja dalam Menuju Pusat Kota}

Para pekerja, ketika sudah berada di pusat kota, mereka biasa berjalan kaki di sekitar tempat kerja pada saat jam makan siang. Adapun selain didominasi oleh kebutuhan makan siang $(63 \%)$ di jam istirahat, pejalan kaki pekerja juga mengisi aktivitasnya dengan berbincang-bincang (13\%), aktivitas duduk-duduk (12\%), bersosialisasi $(6 \%)$ dan sisanya tidak pergi ke mana-mana (4\%) serta aktivitas lainnya (1\%). Adanya aktivitas-aktivitas tersebut tentunya merupakan aktivitas utama yang diharapkan terjadi dari sebuah ruang transisi di mana ruang transisi dapat mewadahi aktivitas seperti duduk-duduk, bersosialisasi, istirahat ataupun untuk berbincang-bincang.

Para pengunjung dan pekerja dalam melakukan pergerakan di pusat kota dengan berjalan kaki, kedua tipe pejalan kaki tersebut memiliki jarak tempuh yang berbeda yang mana pejalan kaki pengunjung memiliki karakteristik berjalan kaki lebih jauh yaitu dengan jarak $200-400 \mathrm{~m}(49 \%)$ dan > $400 \mathrm{~m}(39 \%)$ sedangkan pejalan kaki pekerja bergerak lebih 
pendek yaitu 100 - $200 \mathrm{~m}(60 \%)$, berbeda dari jarak yang ditempuh oleh pejalan kaki pengunjung.
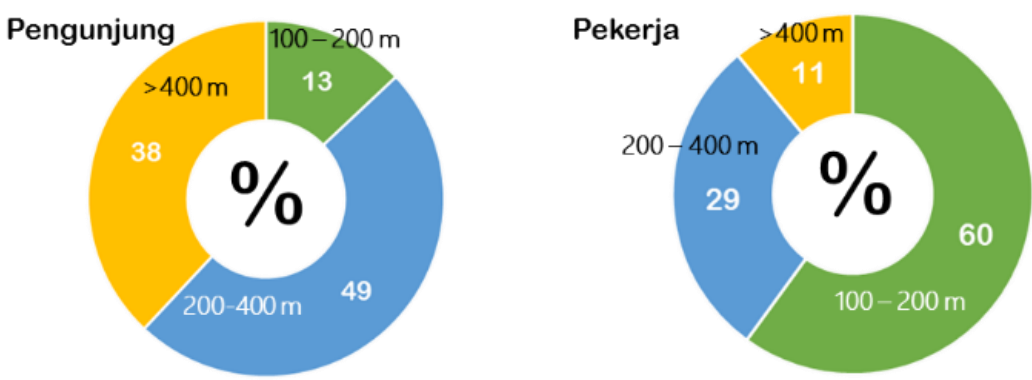

\section{Gambar 5. Jarak Berjalan Kaki Pengunjung dan Pekerja Ketika Berada di Pusat Kota}

Kedua perbedaan tersebut jika dikaitkan dengan aktivitas antara pengunjung dan pekerja, tentu saja berbeda, jika pengunjung melakukan aktivitas di pusat kota dengan kepentingan paling banyak untuk berbelanja dan berjalan-jalan maka aktivitas tersebut menunjukkan bagaimana karakteristik pejalan kaki pengunjung di pusat kota ketika dilakukan dengan tujuan berbelanja dapat melakukan pergerakan lebih jauh tanpa disadari (Untermann, 1984) berbeda dengan para pekerja yang tidak dapat bergerak terlalu jauh dari tempat bekerjanya, hal tersebut tentu saja dipengaruhi oleh faktor waktu/shift kerjanya, di mana paling banyak pekerja melakukan aktivitas berjalan kaki pada saat jam istirahat kerja untuk kepentingan makan siang, sehingga ada batasan waktu yang perlu diperhatikan dari jam istirahat yang ditentukan oleh masing-masing tempat bekerjanya.

\section{Ruang Transisi di Pusat Kota}

Ruang transisi dapat berada di antara ruang publik dan ruang privat sehingga keberadaannya dapat menjadi ruang semi publik yang ditujukan untuk pejalan kaki. Berkaitan dengan pejalan kaki sebagai pengguna ruang transisi, maka terkait dengan bagaimana ruang transisi menjadi sebagai ruang yang ditujukan untuk publik yang mana dari segi pelingkup ruang publik terbagi menjadi tiga tipologi yaitu external public space, internal public space, dan external and internal quasi 'public space' (Carmona, Tim, OC, \& Steve, 2003). Jika dikaitkan dengan ruang transisi, maka bentuk-bentuk ruang transisi yang dapat dapat diidentifikasi yaitu sebagai berikut.

Tabel 3. Identifikasi Bentuk dan Jenis Ruang Transisi di Pusat Kota Bandung

\begin{tabular}{|c|c|c|c|c|c|}
\hline No & \multicolumn{2}{|c|}{ Bentuk } & Definsi & Jenis & $\begin{array}{l}\text { Kondisi yang ada di Pusat } \\
\text { Kota }\end{array}$ \\
\hline 1 & $\begin{array}{l}\text { External } \\
\text { Space }\end{array}$ & Public & $\begin{array}{l}\text { Bidang tanah yang } \\
\text { terletak di antara } \\
\text { kepemilikan lahan } \\
\text { privat, di mana } \\
\text { biasanya berbentuk } \\
\text { ruang luar yang dapat } \\
\text { diakses oleh semua } \\
\text { orang (publik) }\end{array}$ & $\begin{array}{l}\text { Taman Mini/Pocket } \\
\text { Park, Open } \\
\text { Square/Plaza, } \\
\text { Pedestrian Mall, } \\
\text { Taman Linier }\end{array}$ & $\begin{array}{l}\text { Plaza, Pedestrian Mall, } \\
\text { Jalur Hijau }\end{array}$ \\
\hline 2 & $\begin{array}{l}\text { Internal } \\
\text { Space }\end{array}$ & Public & $\begin{array}{l}\text { Fasilitas umum yang } \\
\text { dikelola pemerintah } \\
\text { dan dapat diakses oleh } \\
\text { warga secara bebas } \\
\text { tanpa ada batasan } \\
\text { tertentu }\end{array}$ & Halte Bis & Halte Bis \\
\hline
\end{tabular}




\begin{tabular}{|c|c|c|c|c|}
\hline No & Bentuk & Definsi & Jenis & $\begin{array}{l}\text { Kondisi yang ada di Pusat } \\
\text { Kota }\end{array}$ \\
\hline 3 & $\begin{array}{l}\text { External and } \\
\text { Internal quasi } \\
\text { 'public space' }\end{array}$ & $\begin{array}{l}\text { Fasilitas umum yang } \\
\text { biasanya dikelola oleh } \\
\text { sektor privat dan ada } \\
\text { batasan atau aturan } \\
\text { yang harus dipatuhi } \\
\text { masyarakat } \\
\text { *Tempat makan }\end{array}$ & $\begin{array}{l}\text { Tempat Makan, Mini } \\
\text { Café, Pujasera/Food } \\
\text { Hall, Minimarket Cafe } \\
\\
\text { la kasus di Indonesia, te } \\
\text { rti Pedagang Kaki Lima }\end{array}$ & $\begin{array}{l}\text { Tempat Makan, Mini Café, } \\
\text { Pujasera/ Food Hall, } \\
\text { Minimarket Cafe }\end{array}$ \\
\hline
\end{tabular}

Jenis ruang transisi yang ada di Kawasan Pusat Kota Bandung meliputi plaza, pedestrian mall, jalur hijau, halte bis, serta mini café, pujasera/food hall, dan minimarket café. Selain itu juga terdapat jenis ruang transisi lain yang tumbuh dari sektor informal yaitu Pedagang Kaki Lima (PKL) yang makanan. Adapun keberadaan PKL tersebut cukup banyak didatangi oleh para pekerja juga pengunjung. Berikut kondisi/karakteristik ruang transisi yang ditemui di kawasan studi.

Tabel 4. Kondisi/Karakteristik Ruang Transisi Berdasarkan Bentuk/Jenisnya di Kawasan Studi

\begin{tabular}{|c|c|c|}
\hline No & $\begin{array}{l}\text { Bentuk/ } \\
\text { Jenis }\end{array}$ & Kondisi/Karakteristik \\
\hline 1 & Plaza & $\begin{array}{l}\text { Terdapat dua plaza yaitu pada Plaza Alun-Alun yang menjadi bagian dari halaman Mesjid } \\
\text { Raya Alun-Alun Bandung serta pada Plaza Cikapundung Riverspot yang berada dekat } \\
\text { dengan pedestrian mall yang berada di Jalan Soekarno. Dari kedua plaza tersebut, plaza } \\
\text { Alun-Alun memiliki luasan yang lebih besar dibandingkan dengan plaza Cikapundung } \\
\text { Riverspot, dan yang lebih ramai dikunjungi adalah plaza Alun-Alun. Plaza Cikapundung } \\
\text { Riverspotramai digunakan ketika sedang ada acara pada pedestrian mall Jalan Soekarno, } \\
\text { sehingga keberadaan plaza tersebut memiliki hubungan yang saling menguatkan antara } \\
\text { pedestrian mall dengan plaza. }\end{array}$ \\
\hline 2 & $\begin{array}{l}\text { Pedestria } \\
\text { n Mall }\end{array}$ & $\begin{array}{l}\text { Terdapat dua pedestrian mall pada kawasan studi yang merupakan tipe full pedestrian } \\
\text { mall, yaitu pedestrian mallyang terdapat pada Jalan Dalem Kaum di mana bagian kanan } \\
\text { dan kiri koridor jalan merupakan bangunan komersial deret (shopping street) dan } \\
\text { pedestrian mall yang berada pada Jalan Soekarmo yakni berada di samping Gedung } \\
\text { Sejarah (Gedung Merdeka) dan berada dekat dengan plaza Cikapundung Riverspot. } \\
\text { Ramainya pejalan kaki pada pedestrian mall Jalan Dalem Kaum berlangsung pada saat } \\
\text { akhir pekan sedangkan pedestrian mallyang berada di Jalan Soekarno ketika akhir pekan } \\
\text { dan ketika ada acara/festival yang diselenggarakan. }\end{array}$ \\
\hline 3 & $\begin{array}{l}\text { Jalur } \\
\text { Hijau }\end{array}$ & $\begin{array}{l}\text { Jalur hijau berfungsi sebagai ruang transisi bagi pejalan kaki seperti yang dijumpai pada } \\
\text { pusat kegiatan Alun-Alun yaitu di Jalan Dalem Kaum dan Jalan Alun-Alun Timur. Jalur } \\
\text { hijau tersebut berperan sebagai ruang transisi bagi pejalan kaki di karena kan ruang } \\
\text { tersebut nyatanya dapat sekaligus digunakan untuk aktivitas seperti duduk-duduk, } \\
\text { bersosialisasi bagi pengunjung maupun pekerja di sekitar kawasan studi selain fungsinya } \\
\text { sebagai nilai ekologis lanskap kota }\end{array}$ \\
\hline 4 & Halte Bis & $\begin{array}{l}\text { Halte bis pada kawasan studi dapat berfungsi sebagai titik awal atau akhir berjalan kaki } \\
\text { di mana keberadaan halte berada di samping jalur pedestrian sehingga memudahkan } \\
\text { masyarakat dalam melakukan jangkauan terhadap halte. Halte sebagai tempat } \\
\text { pemberhentian transportasi umum seperti bis, selain bertindak sebagai tempat berhenti } \\
\text { kendaraan, maka ia dapat berperan juga sebagai ruang transisi bagi pejalan kaki. Pada } \\
\text { kawasan studi terdapat dua halte yang dapat berperan sebagai ruang transisi, yaitu Halte } \\
\text { Alun-Alun yang berada di Jalan Asia Afrika dan Halte yang berada di Jalan Banceuy di } \\
\text { mana Halte Alun-Alun merupakan halte yang memiliki luas yang cukup besar } \\
\text { dibandingkan dengan Halte Banceuy. }\end{array}$ \\
\hline 5 & Mini Café & $\begin{array}{l}\text { Mini Café pada kawasan studi terdapat pada pusat kegiatan ABC (Jalan Alkateri) serta } \\
\text { banyak ditemui pada pusat kegiatan Alun-Alun (Jalan Braga) Adapun café ini menjual } \\
\text { makanan dan minimum ringan yang dapat dimanfaatkan oleh pejalan kaki, mini café yang } \\
\text { ada pada kawasan studi paling banyak hanya menempati lantai } 1 \text { bangunan }\end{array}$ \\
\hline 6 & $\begin{array}{l}\text { Pujasera/ } \\
\text { Food Hall }\end{array}$ & $\begin{array}{l}\text { Pujasera/food hall, pujasera dapat ditemui di Jalan Dalem Kaum dan Jalan Kepatihan, } \\
\text { Pujasera di Jalan Dalem Kaum memanfaatkan lantai UG pada bangunan mall MD Plaza, } \\
\text { dan lantai } 1 \text { pada bangunan Kings serta lantai } 1 \text { bangunan swarna Jalan Asia Afrika. }\end{array}$ \\
\hline
\end{tabular}




\begin{tabular}{|c|c|c|}
\hline No & $\begin{array}{l}\text { Bentuk/ } \\
\text { Jenis }\end{array}$ & Kondisi/Karakteristik \\
\hline 7 & $\begin{array}{l}\text { Minimark } \\
\text { at Cafe }\end{array}$ & $\begin{array}{l}\text { Minimarket Café dapat ditemui pada Jalan Braga yaitu seperti Indomaret, Circle K, } \\
\text { Alfamart, dan Mor, Circle K pada Kantor Pos Jalan Asia Afrika serta Yogya Express pada } \\
\text { Jalan Kepatihan. Minimarket pada bangunan tersebut menjadi pengisi bentuk active edge } \\
\text { pada koridor jalan. }\end{array}$ \\
\hline 8 & $\begin{array}{l}\text { Rumah } \\
\text { Makan }\end{array}$ & $\begin{array}{l}\text { Rumah Makan atau dapat juga berupa restoran pada kawasan studi tidak berkumpul di } \\
\text { satu area saja tapi juga menyebar di beberapa pusat kegiatan yang meliputi Pasar Baru, } \\
\text { ABC, dan Alun-Alun. Namun rumah makan yang banyak ditemui yaitu di koridor Jalan } \\
\text { Braga yang mana rumah makan menempati 1-2 lantai bangunan }\end{array}$ \\
\hline 9 & PKL & $\begin{array}{l}\text { Terdapat tempat-tempat makan pada kawasan studi, terutama pada pusat kegiatan Pasar } \\
\text { Baru dan ABC didominasi oleh keberadaan Pedagang Kaki Lima (PKL) berupa gerobak } \\
\text { disertai warung makan tenda yang menjual makanan }\end{array}$ \\
\hline
\end{tabular}

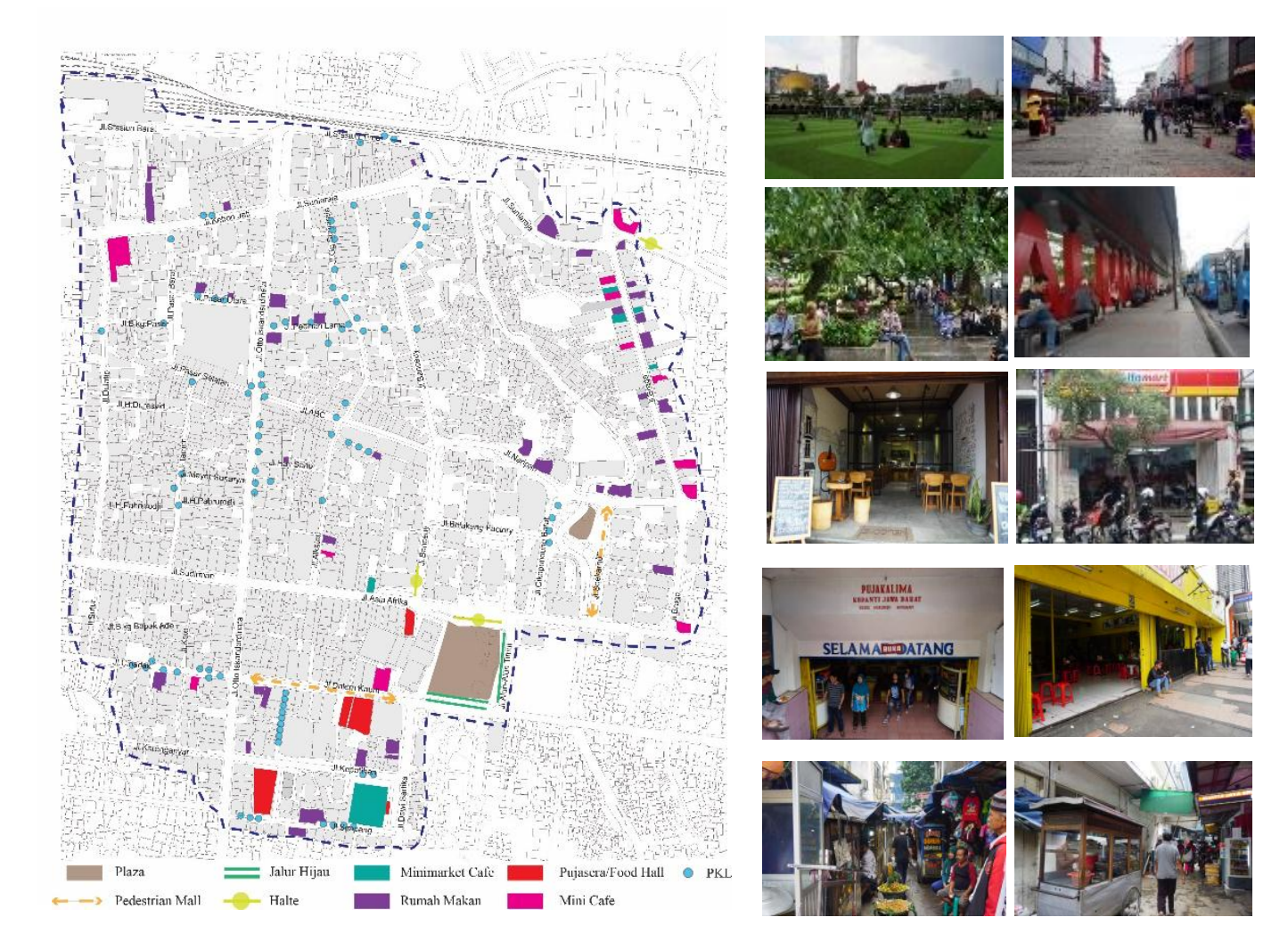

Gambar 6. Sebaran Jenis Ruang Transisi di CBD Kota Bandung

Kawasan pusat kota sebagai kawasan yang memiliki peluang besar terhadap keberadaan ruang transisi memunculkan penggunaan ruang transisi berdasarkan pola-pola pergerakan pejalan kaki pengunjung maupun pekerja saat berada di pusat kota, yaitu berasal dari titik-titik pemberhentian kendaraan umum dan kendaraan pribadi serta beberapa tempat tujuan yang didatangi oleh pengunjung maupun pekerja (Gambar 7). Pada kawasan studi terdapat titik-titik yang menjadi pergerakan awal pengunjung dan pekerja yang mana telah dijelaskan sebelumnya bahwa pergerakan tersebut didominasi oleh pergerakan kendaraan pribadi dan setelahnya kendaraan umum, sehingga titik-titik pemberhentian akan transportasi umum dan kendaraan pribadi menjadi perhatian penting sebagai penghubung keberadaan ruang transisi di pusat kota. Hal tersebut pada akhirnya menghasilkan pola berjalan kaki pedestrian yang mana dari pola tersebut juga didapat keterhubungannya dengan ruang transisi yang ada di pusat Kota Bandung (Gambar 7). 


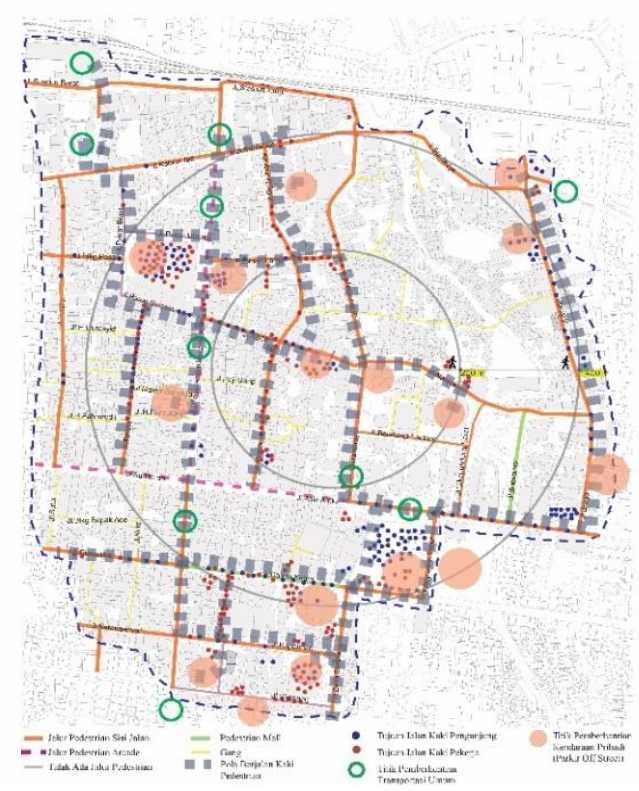

a

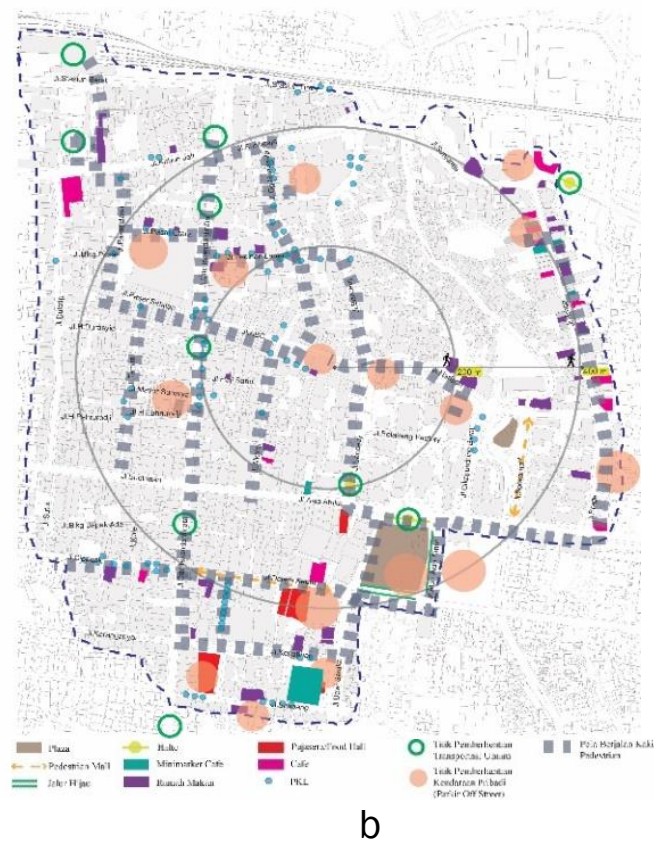

\section{Gambar 7. (a) Integrasi Titik Pemberhentian Kendaraan dengan Pola Berjalan Kaki Pedestrian; (b) Integrasi Pola Berjalan Kaki Pedestriandengan Keberadaan Ruang Transisi}

\section{Preferensi Pejalan Kaki Terhadap Ruang Transisi}

Mengenai preferensi pejalan kaki terhadap bentuk/jenis ruang transisi, dari beberapa jenis ruang transisi yang berhasil diidentifikasi di kawasan pusat Kota Bandung, maka jenis ruang yang paling diminati adalah ruang transisi dalam bentuk external public space dengan jenis pedestrian mall, hal tersebut ditunjukkan dengan $45 \%$ pejalan kaki paling banyak memilih jenis ruang transisi dalam jenis pedestrian mall. Pedestrian mal yang terdapat di Kawasan Pusat Kota Bandung berada di Jalan Dalem Kaum dan Jalan Soekarno.

Hal tersebut sejalan jika dikaitkan dengan lingkungan fasilitas pedestrian yang dapat mendukung keberadaan ruang transisi, di mana pejalan kaki banyak memililih kriteria lingkungan fasilitas pedestrian dengan jalur pejalan kaki yang memberikan kemudahan penyeberangan yaitu mencapai $32 \%$ disusul dengan $25 \%$ pejalan kaki yang memilih lingkungan fasilitas pejalan kaki dengan rute yang menarik dan $19 \%$ jalur pejalan kaki dengan rute yang jelas.

Begitu juga dengan karakter ruang yang tercipta pada ruang transisi, di mana ruang transisi berdasarkan preferensi terbesar pejalan kaki dari segi pengaturan fisik membutuhkan ruang yang memberikan kecocokan dari segi lokasi, warna, bentuk, dan material yang tepat bagi suatu ruang (33\%). Adapun dari segi pengaturan publik, ruang transisi sebagai ruang peralihan bagi pejalan kaki atau ruang 'pertemuan' bagi pejalan kaki di pusat kota untuk memulai aktivitas baru dari aktivitas yang terjadi sebelumnya yang diminati oleh pejalan kaki adalah ruang yang memberikan ketersediaan tempat duduk (31\%) dan dapat dipergunakan untuk relaks (43\%). Hal tersebut berkaitan dengan keberagaman aktivitas yang terjadi di pusat kota, di mana dengan aktivitas berupa berbelanja, jalan-jalan merupakan aktivitas berjalan kaki secara dinamis (Rapoport, 1990), sehingga dalam pergerakannya tentunya membutuhkan ruang dengan aktivitas duduk-duduk yang dapat memfasilitasi pejalan kaki ketika berhenti untuk sementara waktu dalam rangka bergerak untuk menuju ke tempat berikutnya. 
Adapun berkaitan dengan ruang transisi yang jenisnya external and internal quasi 'public space', dalam hal ini yaitu berupa tempat makan, dengan sifat kepemilikannya yang privat namun ditujukan untuk publik, $86 \%$ pejalan kaki memiliki preferensi terhadap kondisi ruang yang memanfaatkan lantai satu pada bangunannya menjadi lebih publik dengan kehadiran ruangnya yang membentuk active edge/street frontage, sehingga pejalan kaki dapat memanfaatkan 'ruang luar' pada lantai satu bangunan untuk aktivitas seperti dudukduduk, berbincang-bincang, makan, ataupun bersosialisasi. Selain daripada itu ruang transisi tentunya dapat memberikan makna dari segi kesesuaian visual di mana pejalan kaki memiliki respon akan adanya sebuah ruang tersebut.

\section{Prinsip Perancangan Ruang Transisi}

Penyusunan prinsip perancangan pada sebuah ruang transisi di pusat kota disusun berdasarkan pertimbangan-pertimbangan yang memperhatikan preferensi serta kondisi fisik di mana masing-masing pertimbangan tersebut menjadi suatu prinsip perancangan. Prinsip perancangan yang dirumuskan pada penelitian ini yaitu prinsip perancangan ruang transisi secara umum dalam konteks kawasan CBD berdasarkan komponen bentuk, akses, dan karakter ruang serta rumusan prinsip perancangan ruang transisi berdasarkan bentuk/jenisnya, di mana pada jurnal ini hanya akan dibahas khususnya jenis ruang transisi dengan jenis pedestrian mall, yang mana menjadi paling diminati oleh pejalan kaki berdasarkan preferensi mereka terhadap bentuk ruang.

\section{Prinsip Perancangan Ruang Transisi Secara Umum dalam Konteks CBD}

Perancangan ruang transisi di Kawasan Pusat Kota (CBD) dilakukan dengan tujuan untuk mengakomodasi kebutuhan pergerakan pejalan kaki terhadap suatu ruang yang dapat difungsikan sebagai ruang pertemuan pejalan kaki, ruang peristirahatan sementara, ruang yang mewadahi aktivitas setelah dilakukan aktivitas yang sebelumnya dilakukan oleh pejalan kaki di pusat kota (bekerja, berbelanja, jalan-jalan, rekreasi, dan lain sebagainya).

Tabel 5. Komponen Penyusunan Prinsip Perancangan Ruang Transisi

\begin{tabular}{ll}
\hline Komponen & \\
\hline Bentuk & $\begin{array}{l}\text { Bentuk ruang yang diidentifikasi berdasarkan sifat ruang tersebut yaitu secara publik, ruang transisi } \\
\text { dapat digunakan oleh pejalan kaki siapa-pun, ruang publik tersebut berdasarkan pelingkupnya } \\
\text { berbentuk external public space, internal public space, dan external and Internal quasi-'public'space }\end{array}$ \\
Akses & $\begin{array}{l}\text { Melibatkan permeabilitas di sekitar objek ruang yang dipengaruhi oleh jaringan jalan, bentuk blok, } \\
\text { kontinuitas sebuah ruang berdasarkan mobilitas yang berasal dari integrasi antar moda serta }\end{array}$ \\
& $\begin{array}{l}\text { lingkungan fasilitas pedestrian terkait jalur pejalan kaki dan jarak berjalan kaki yang dilakukan oleh } \\
\text { pejalan kaki }\end{array}$ \\
Karakter & Kualitas fisik yang mencakup pengaturan fisik (physical setting), pengaturan publik (public setting), \\
Ruang & aktivitas sebuah ruang dari vitalitas (vitality), keberagaman (diversity), serta lingkungan responsif \\
& dari segi keterbacaan (legibility), kesesuaian secara visual (visual appropriatness) dan lingkungan \\
& responsif yang memberikan kesempurnaan ruang (richness) dan ketahanan (robustness)
\end{tabular}

Tujuan perancangan ruang transisi di kawasan studi yang telah disampaikan di atas menjadi sangat penting untuk dirumuskan dalam sebuah rumusan prinsip perancangan, hal tersebut berkaitan dengan bagaimana suatu kawasan pusat kota yang memiliki dominasi fungsi komersial, shopping street dapat menarik orang untuk berjalan kaki, yang mana pada akhirnya kebutuhan ruang transisi menjadi penting di dalam mendukung aktivitas dan mobilitas pejalan kaki sehingga Kawasan Pusat Kota (CBD) perlu mengakomodasi akan kebutuhan ruang tersebut. Terdapat beberapa hal yang berkaitan dengan perumusan prinsipprinsip perancangan ruang transisi yang mana didasarkan atas beberapa pertimbangan dasar yaitu sebagai berikut:

1. Pergerakan pejalan kaki pengunjung di kawasan studi yang rata-rata mencapai beberapa tempat tujuan menempuh jarak sedang $(200-400) \mathrm{m}$ dan jauh $(>400 \mathrm{~m})$ 
2. Pergerakan pejalan kaki pekerja di kawasan studi yang rata-rata menempuh jarak 100 $200 \mathrm{~m}$, di waktu jam istirahat untuk kebutuhan makan siang

3. Kebutuhan pejalan kaki (pengunjung dan pekerja) akan suatu ruang yang dapat digunakan untuk aktivitas seperti duduk-duduk dan berbincang-bincang sebagai aktivitas baru yang dilakukan setelah aktivitas sebelumnya

4. Keberadaan bentuk ruang transisi bagi pejalan kaki yang dapat bersifat privat-publik (semi publik)

5. Masing-masing bentuk/jenis ruang transisi sama-sama dapat mengakomodasi akan kebutuhan ruang bagi pejalan kaki, namun masing-masing dari bentuk tersebut memiliki perangkat perancangan yang berbeda-beda hal tersebut berkaitan dengan bentuknya, aktivitas dan karakter ruangnya serta berdasarkan potensi dan preferensi pejalan kaki terhadap bentuk/jenis ruang transisi tersebut. Dengan demikian, penyusunan prinsip ruang transisi ini melibatkan tiga komponen yang meliputi komponen bentuk, akses, dan karakter ruang.
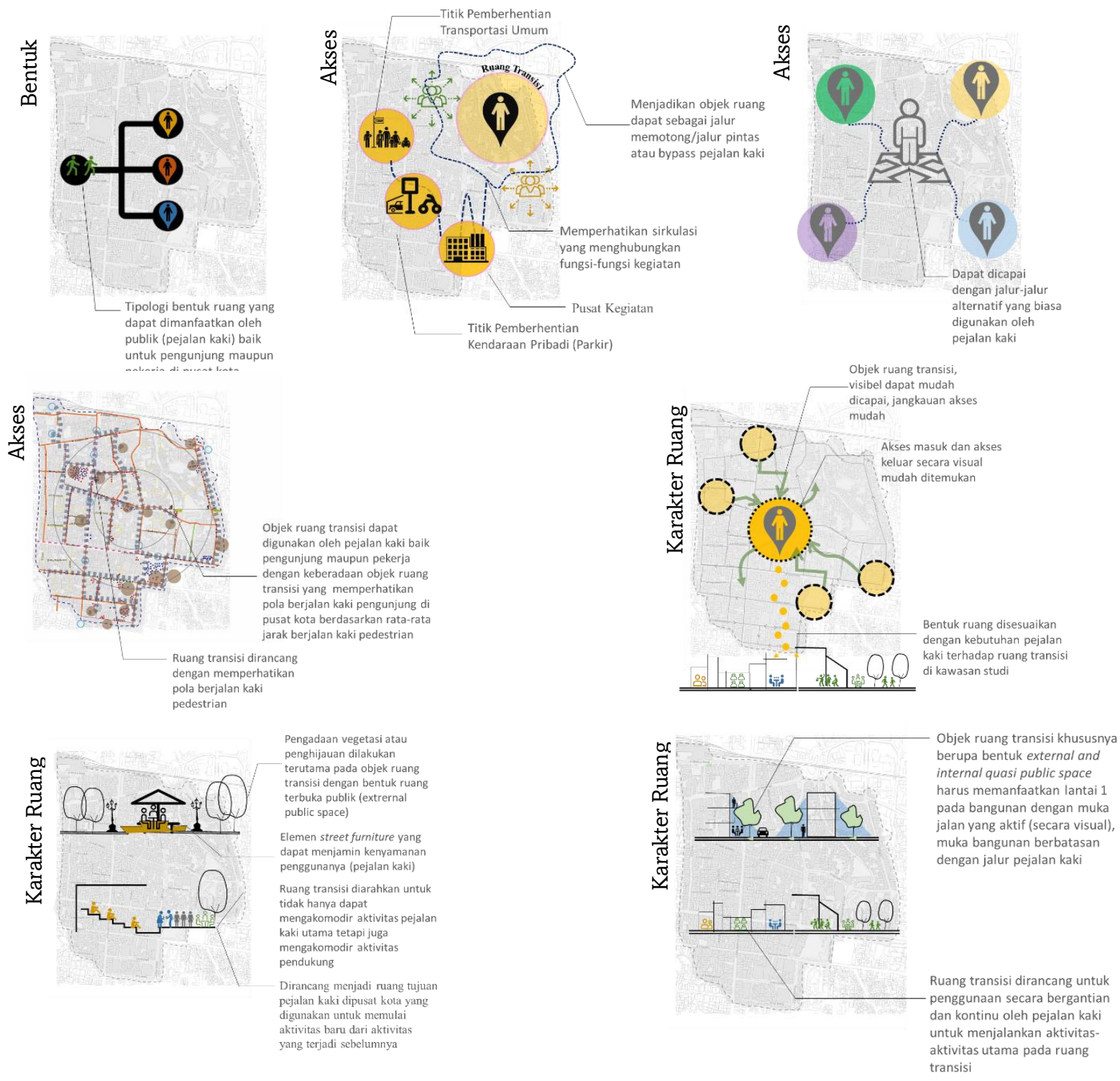

Gambar 8. Diagram Ilustrasi Prinsip Perancangan Umum Ruang Transisi dalam Konteks CBD 


\section{Prinsip Perancangan Ruang Transisi Jenis Pedestrian Mall}

Jika dikaitkan dengan preferensi pejalan kaki terhadap bentuk/jenis ruangnya, maka ruang transisi yang paling diminati yaitu dalam bentuk external public space dengan jenis pedestrian mall. Adapun pedestrian mall yang berada pada kawasan studi dengan potensinya sebagai ruang transisi, terdapat pada Jalan Kaum, di mana dengan hadirnya pedestrian mall tersebut, maka prinsip perancangannya disusun berdasarkan atas pertimbangannya sebagai potensi ruang dalam jenis itu, yakni sebagai berikut:

1. Keberadaannya yang secara visual mudah ditemukan

2. Kemudahan akses pergerakan pejalan kaki dalam memanfaatkan ruang akibat berada di sekitar kawasan pertokoan

3. Fungsi/aktivitas yang ada di sekeliling pedestrian mallikut mendorong pejalan kaki untuk memanfaatkan ruang tersebut

4. Menjadi jalur pejalan kaki yang mempunyai peluang untuk rute yang menarik

5. Ruang yang memberikan kecocokan dari segi lokasi, warna, bentuk, material, dan cocok dengan nilai bangunan di kawasan

6. Dilengkapi dengan kehadiran aktivitas pendukung

7. Ketersediaan tempat duduk

8. Kemudahan dalam melihat aktivitas yang terjadi di seputar ruang

9. Penggunaan ruang dengan aktivitas duduk-duduk, istirahat sekaligus berbincang-bincang serta ruang transisi dapat digunakan untuk relaks

10.Lingkungan yang responsif dalam hal kesesuaian visual (visual appropriatness) dimana mendukung keterbacaan sehingga mudah dikenal

11.Ruang yang dapat memberikan potensi kesempurnaan (richness) secara visual dan non visual (sense of hearing, sense of touch, sense of smell, sense of motion)

Berdasarkan pertimbangan atas potensi pedestrian mall sebagai ruang transisi di pusat kota, maka prinsip perancangannya yaitu sebagai berikut:

Tabel 6. Prinsip Perancangan Pedestrian Mall

\begin{tabular}{|c|c|c|}
\hline Pertimbangan & Prinsip Umum & $\begin{array}{l}\text { Prinsip Khusus } \\
\end{array}$ \\
\hline 1 & $\begin{array}{l}\text { Akses pejalan kaki di setiap sisi } \\
\text { area }\end{array}$ & $\begin{array}{l}\text { Keberadaan pedestrian mall dekat dengan titik } \\
\text { pemberhentian kendaraan umum/pribadi, fitur penanda } \\
\text { pada akses masuk dan keluar }\end{array}$ \\
\hline 2 & $\begin{array}{l}\text { Orientasi keberadaan pertokoan } \\
\text { langsung menghadap ke badan } \\
\text { jalan }\end{array}$ & $\begin{array}{l}\text { Pintu masuk bangunan pertokoan di Jalan Dalem Kaum } \\
\text { berupa pintu masuk yang aksesibel tanpa penutup } \\
\text { penghalang (transparan) }\end{array}$ \\
\hline 3 & $\begin{array}{l}\text { Keberadaan pedestrian mall } \\
\text { berada pada tengah simpul- } \\
\text { simpul kegiatan }\end{array}$ & $\begin{array}{l}\text { Didukung dengan jalur penghubung trotoar untuk } \\
\text { menghubungkan fungsi/aktivitas yang ada di sekeliling } \\
\text { pedestrian mall }\end{array}$ \\
\hline 4 & $\begin{array}{l}\text { Memberi daya tarik ruang untuk } \\
\text { pejalan kaki }\end{array}$ & $\begin{array}{l}\text { Keberadaan etalase pertokoan di sepanjang Jalan Dalem } \\
\text { Kaum, memberikan elemen steet furniture pada koridor } \\
\text { jalan }\end{array}$ \\
\hline 5 & $\begin{array}{l}\text { Tidak ada } \\
\text { obstacle/penghalang bagi } \\
\text { pejalan kaki untuk mengakses } \\
\text { ruang } \\
\text { Penggunaan material yang } \\
\text { berkaitan dengan durability } \\
\text { street furniture }\end{array}$ & $\begin{array}{l}\text { Menutup akses masuk kendaraan bermotor pada } \\
\text { segmen Jalan Dalem Kaum } \\
\text { Meniadakan keberadaan parkir on-street di sekitar } \\
\text { ruas Jalan Dalem Kaum }\end{array}$ \\
\hline 6 & $\begin{array}{l}\text { Aktivitas pendukung pada } \\
\text { pedestrian mall menjadi daya } \\
\text { tarik di luar aktivitas utama } \\
\text { (duduk-duduk, istirahat, } \\
\text { berbincang-bincang, }\end{array}$ & $\begin{array}{l}\text { Memberikan aktivitas pendukung berupa keberadaan } \\
\text { kios penjualan di beberapa titik } \\
\text { Memberikan aktivitas pendukung berupa perfomance } \\
\text { di beberapa titik }\end{array}$ \\
\hline
\end{tabular}




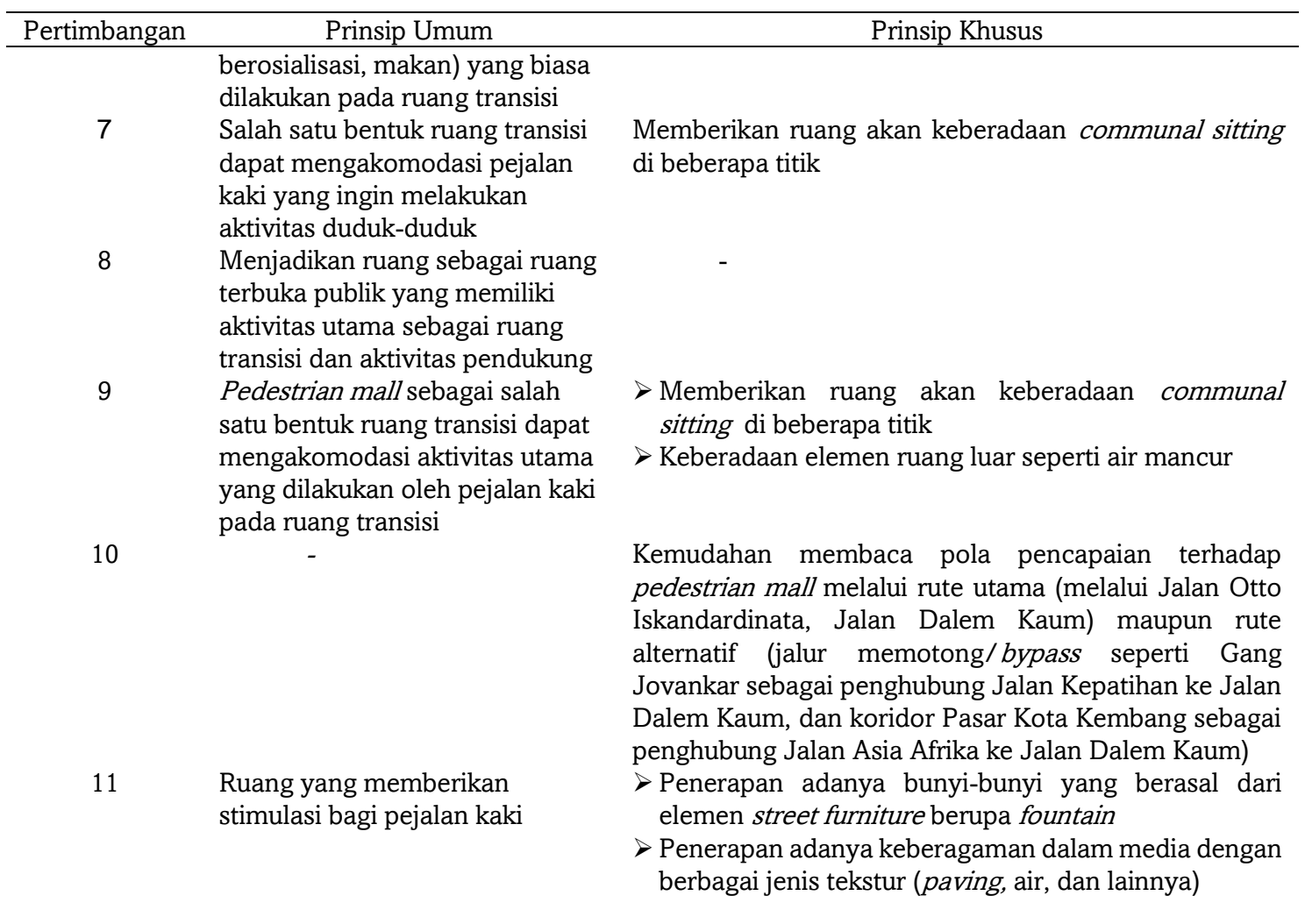

\section{KESIMPULAN}

Ruang transisi di kawasan pusat kota memang seharusnya menjadi pertimbangan di dalam memenuhi fasilitas bagi pedestrian. Ruang transisi dibutuhkan tidak hanya dapat ditujukan sebagai pengunjung yang berjalan kaki saja tetapi juga membuka peluang terhadap para pekerja di Kawasan Pusat Kota yang dapat berjalan kaki menuju ruang transisi sebagai tempat beristirahat mereka. Secara umum kebutuhan ruang transisi di CBD dipengaruhi oleh komponen bentuk, akses, dan karakter ruang. Berdasarkan komponen tersebut terdapat beberapa kesimpulan prinsip perancangannya yaitu (1) ruang transisi dari segi bentuk, dirancang dengan tipologi bentuk ruang Privat-Publik (Semi Publik) yang dapat dimanfaatkan oleh publik (pejalan kaki) baik untuk pengunjung maupun pekerja di pusat kota, (2) ruang transisi dari segi akses, yaitu kehadiran akan objek ruang tersebut perlu memperhatikan pola berjalan kaki pedestrian dimulai dari kedatangan ke pusat kota melalui titik-titik pemberhentian transportasi umum maupun pribadi serta pergerakan berjalan kaki pedestrian terhadap tempat-tempat tujuan di sekitar objek ruang, (3) ruang transisi dari segi karakter ruang mampu mengakomodasi aktivitas utama pejalan kaki pada ruang transisi (duduk-duduk, makan, bersosialisasi, istirahat, dan berbincang-bincang), selain itu, keberadaan ruang transisi dirancang dapat menjadi titik akhir perjalanan sebelum ke titik perjalanan ke aktivitas selanjutnya setelah aktivitas sebelumnya atau juga ruang transisi dapat menjadi titik awal pergerakan pejalan kaki yang mana ruang transisi dirancang dengan menempati layout ruang yang memberikan kemudahan membaca pola pencapaian terhadap objek ruang baik melalui jalur utama maupun jalur alternatif

Berdasarkan preferensi pejalan kaki, kebutuhan ruang transisi di CBD Kota Bandung dengan bentuknya yaitu external public space, internal public space, intenal, dan external and Internal quasi 'public space', yang paling diminati oleh pejalan kaki adalah ruang transisi dengan bentuk external public space, yaitu jenis pedestrian mall, pedestrian mall menjadi ruang terbuka publik yang menciptakan kondisi pejalan kaki dapat secara leluasa berlalu- 
lalang pada koridor jalan dengan tidak terganggu oleh kendaraan yang melintas dalam artian juga dapat menciptakan lingkungan fasilitas pedestrian yang memberikan kemudahan penyeberangan bagi para pejalan kaki, sehingga pada akhirnya koridor tersebut menjadi ruang pertemuan pejalan kaki yang memiliki karakter penggunaan ruang dengan keutamaan aktivitas yang terjadi seperti duduk-duduk, istirahat, sekaligus berbincang-bincang. Hadirnya preferensi akan aktivitas tersebut maka tuntutan karakter ruang yang tercipta untuk ruang transisi jenis tersebut perlu diperhatikan dari segi kehadiran aktivitas pendukung, ketersediaan tempat duduk, kemudahan dalam melihat aktivitas yang terjadi di seputar ruang serta penggunaan ruang dengan aktivitas duduk-duduk, istirahat sekaligus berbincangbincang serta ruang transisi yang dapat digunakan untuk relaks.

\section{DAFTAR PUSTAKA}

Asadi, M., Tahir, M. M., Shabani, M. M., \& Arjmandi, H. (2015). Introduction To Transition Space In Contemporary Iranian Housing Typology. e-Bangi (Journal of Social Sciences and Humanities), 10(1), 184-194. Dipetik Februari 7, 2017, dari http://journalarticle.ukm.my/9335/1/184194_Mohsen_Contemporary_Iranian_Housing.pdf

Bentley, I., Alcock, A., Murrain, P., McGlynn, S., \& Smith, G. (1985). Responsive Environments a Manual For Designers. London: Architectural Press.

Carmona, M., T. H., OC, T., \& S. T. (2003). Public Places Urban Spaces: The Dimension of Urban Design. Oxford: Architectural Press.

Creswell, J. W. (2003). Research Design-Qualitative, Quantitative, and Mixed Methods Approaches. Thousand Oaks, California: Sage Publication.

El-Fattah El-Mokadem, A. A., Sallam, I., \& Salah El-Samaty, H. M. (2013). Human Dimension as an Effective Aspect In the Perception of Transition Spaces. Research Gate, 1-17. Dipetik Februari 7, 2017, dari https://www.researchgate.net/publication/281581566_Human_Dimension_as_an_Effective_Aspect_ In_the_Perception_of_Transition_Spaces

Kent, S. (1990). Domestic Architecture and The Use of Space: An Interdiciplinary Cross-Cultural Study . Melbourne: Press Syndicate of the University of Cambridge.

LLwelyn-Davies. (2000). Urban Design Compendium. London: English Partnerships The House Corporation.

Montgomery, J. (1998). Making a city: Urbanity, vitality and Urban Design. Journal of Urban Design, 93-116.

Nassar , U. A., \& El-Samaty , H. S. (2007). Transition Space in Higher Education Building as an Efficient "Behaviour Setting" Model. International Journal of Innovative Research in Science, Engineering and Technology (IJIRSET), 8304-8319.

Pawitro, U. (2015). Peningkatan Aspek 'Keindahan Kota (The Urban Esthetic) di Kawasan Pusat Kota. Media Matrasin, 1-16.

Porteus, J. D. (1997). Environment and Behaviour.Planning and Everyday.Urban Life. Boston: Addison-Wesley. Rapoport, A. (1990). History and Precedent in Environtmental Design . New York: Plenum Press.

Rencana Tata Ruang Wilayah (RTRW) Kota Bandung 2011-2031. Bandung: Walikota Bandung Provinsi Jawa Barat.

Schulz, N., \& Christiani. (1971). Existence, Space and Architecture. Praeger Publishers.

Shirvani, H. (1985). The Urban Design Process. New York: Van Nostrand Reinhold Company.

Singh, R. (2015). Understanding Transition Spaces. Dissertation, Sushant School of Art and Architecture, India. Sugiyono. (2005). Memahami Penelitian Kualitatif. Bandung: Alfabeta.

Surasetja, I. (2007). Fungsi, Ruang, Bentuk dan Ekspresi Dalaa Arsitektur. Bahan Ajar : TA 110 - Pengantar Arsitektur - 2007 . Program Studi Arsitektur Jurusan Pendidikan Teknik Bangunan - FPTK - UPI. $\begin{array}{llll}\text { Dipetik Januari } & 30, & 2017, & \text { dari }\end{array}$ http://modul.mercubuana.ac.id/files/ft/TEKNIK\%20ARSITEKTUR/Seminar/Laporan\%20Seminar/ Tahun\%202015/Agung\%20Dwi\%20Antara(41210110015)/JURNAL\%20REFERENSI/JURNAL\%20P DF/FUNGSI_RUANG_BENTUK_DAN_EKSPRESI_DALAM_ARSITEKTUR-libre.pdf

Ujang, N. (2010). Place Attachment and Continuity of Urban Place Identity. Asian Journal of EnvironmentBehaviour Studies, 61-76.

Untermann, R. K. (1984). Accomodating The Pedestrian:Adapting Towns and Neighborhoods for Walking and Bcycling. Michigan: Van Nostrand Reinhold.

Utami, W. N., \& Kesuma, H. E. (2016). Identifikasi Faktor Kebutuhan 'Area Transisi' : Persepsi Pejalan Kaki Terhadap Jarak Berjalan Kaki di Kawasan Pusat Kota Bandung. IPLBI(hal. E 37- E 44). Malang: Ikatan Peneliti Lingkungan Binaan (IPLBI). 